\title{
THE FUNCTION AND POSITION OF PENGHULU IN RAFFLES' KITAB HUKUM MANUSCRIPT (1814)
}

\author{
Hazmirullah, Titin Nurhayati Ma'mun, Reiza D. Dienaputra, U. Sudjana \\ Universitas Padjadjaran, Bandung - Indonesia \\ Corresponding author: azmeer125@gmail.com
}

\begin{abstract}
In this article, we discuss the function and position of penghulu in Java in the second decade of the nineteenth century. The object of this study is a manuscript from the British Library collection, coded Mss Eur D/742.1, ff. 155-166, that was issued by Thomas Stamford Raffles, the LieutenantGovernor of Java, and Its Dependencies, on 11 February 1814. The manuscript actually regulates the general justice system. However, in this article, we will only discuss a number of rules that are directly related to the function and position of penghulu in the justice system. The paper will show that penghulu, in Raffles' regulation, was functioned as an expert to be presented to a court. He must expound about Islamic law or customary law related to cases that were being handled by the court. In fact, when it was first formed in the early days of the Demak Sultanate (1475-1554), the penghulu was a representative of the sultan and is held responsible for the implementation of the rules of Islam. Meanwhile, in the field of law, the penghulu was head of the court.
\end{abstract}

Keywords: Manuscript, Kitab Hukum, Raffles, Penghulu, Java.

\section{Introduction}

Most of Indonesian people today have a single understanding about the term "penghulu". They perceive penghulu as a person who has a mandate from the state to marry off two persons'. Such understanding is not entirely wrong if we refer to the regulations issued by the Indonesian government. One of them is the Regulation by the Minister of Ministry of Religious affairs No 30 of 2015 regarding $W$ ali Hakim. Article 1 Paragraph (3) of the regulation stated that 'Penghulu is 
a Government Employee; he is a marriage registrar who is given full duties, responsibilities, authorities, and rights by the Minister of Ministry of Religious affairs or an appointed official that is in accordance with the current regulation whose job is to supervise marriage/referrals according to Islam and the kepenghuluan activities'.

The word "penghulu", according to the online version of the Kamus Besar Bahasa Indonesia, is from the root "bulu". It has five meanings, they are as follows 1) 'the leader', 2) 'the head; the chief, 3) 'the customary head', 4) 'the head of Islamic affairs in a district/regency or a municipality, and 5) 'the advisor of Islamic affairs in the district court; qä $i_{i}$. Nonetheless, the four meanings of the latter are included in the "classic" category, indicating that the words were used in classical Malay literature. If we refer to Javanese culture, as written in Serat Wadu Aji manuscript, the meanings of "pengbulu" are 'sesirab' (the head) or 'pangajeng' (the leader or the chief).

The duty of penghulu which had been understood by most of Indonesian people today actually is a very small part of its roles and functions in the past. During the Demak Sultanate (1475-1554 AD, the penghulu was an official who was one level under the sultan (similar with patib and adipati); and was given responsibility to ensure that the teachings of Islam were implemented in the sultanate region. The penghulu undertook one (of three) of the sultan responsibilities that is the role as the religious leader. One of most prominent functions of the pengbulu in the time was being the head of the court. Therefore, the penghulu must be a person who had comprehensive understandings about Islamic law (fiqh) so that the legal process could be properly implemented in accordance to that.

However, our research shows different findings about penghulu in a manuscript of the British Library collection coded Mss. Eur. D. 742/1, ff. 155-166 (hereinafter called as the Kitab Hukum manuscript, referring to the 3 rd line of the text). The manuscript written on 11 February 1814 that was initiated by Thomas Stamford Raffles stated that penghulu in Java was no longer the head of the court. Rather, he merely act as an "expert", the role that still continues until today's era. Penghulu was presented to the court playing role as an expert and being asked for opinions about all cases, both civil cases and criminal cases, within the courts. Thus, based on the Kitab Hukum manuscript, penghulu

${ }^{1}$ https://kbbi.kemdikbud.go.id/entri/penghulu. 
at the time no longer has the authority to try a case, a role mandated to him during the Demak Sultanate.

This finding is surely interesting to be explored further. Therefore, this paper tried to explore the role and position of penghulu in Java as explained and told by the Kitab Hukum manuscript. The next question then is what are the factors that had influenced Raffles in his issuance of the regulation? Furthermore, we will place the content of the Kitab Hukum manuscript in the history of the judicial system in Java, especially regarding the function and position of the pengbulu, since the period of the Demak Sultanate.

\section{Contents of the Kitab Hukum Manuscript}

The study of the Kitab Hukum manuscript is based on "digital copy" that we had obtained through the website www.bl.uk ${ }^{2}$. It is stated there that the manuscript is a "Malay translation of Police and Judicial Regulations, signed \& sealed by Raffles, 'Letnan Gubernur yang terhormat atas Pulau Jawa dan takluknya', written in Java, February 11 th, 1814". According to Bastin, before being collected by the British Library $^{3}$, all collections belong to Thomas Stamford Raffles had been kept by Mrs. Rosdew Drake in Scotland. When she died in 1970, the collection was inherited to her son, John Raffles Flint Drake. He then agreed to lend all of Raffles' legacy-including letters, paintings, and bust-- to the Indian Office Library (now a part of the British Library). Since 10 November 1970, through an acknowledgment letter, the "Raffles Family Collection" had officially become a part of the Indian Office Library collection with a permanent loan status. In 2007, Mr. Drake's heir agreed to sell the collection to the British Library.

\footnotetext{
2 We have asked for permission orally from Annabel Teh Gallop, the Lead Curator of Southeast Asian Materials at the British Library. We had met in the 16th International Symposium of the Nationwide Manuscript Society (Manassa) at the National Library, Jakarta, which was held on September 26-29th, 2016; also in International Seminar on Pernaskahan Nusantara at Sebelas Maret University, Surakarta, September 25-2, 2017.

3 John Bastin, Letters of Sincerity: The Raffles Collection of Malay Letters (1780-1824, A Descriptive Account with Notes and Translation) (Kuala Lumpur: The Malaysian Branch of the Royal Asiatic Society, 2009), p. xii.
} 
Picture 1. The front and the back page of the Kitab Hukum manuscript.
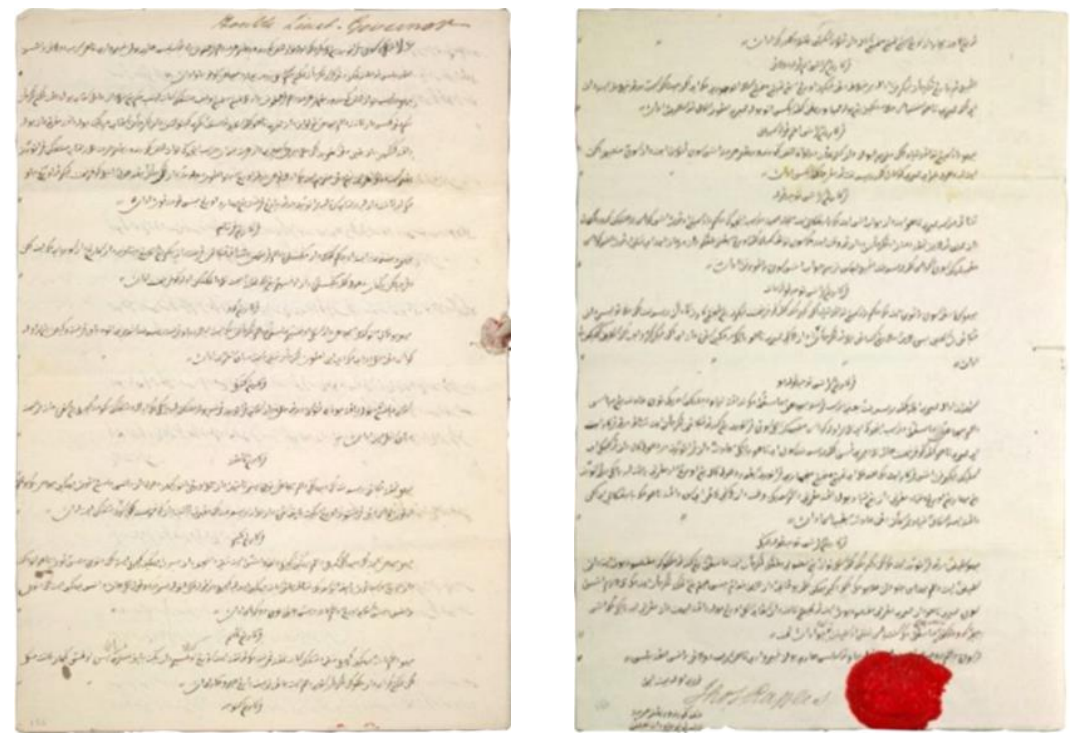

The manuscript that consists of 12 sheets of European paper and coded starting with "f.155" to "f.166" are collected in one katern (booklet). Unfortunately, we did not find detailed information about the type of European paper used as well as the size of the paper. The text is written, recto-verso, on eleven and a half sheets of paper (23 pages) using Jawi (Malay-Arabic) script and Malay language, with the right-left orientation (as how Arabic script is written). While The last page (166 verso; page 24) is left empty. Based on the colophon, the Kitab Hukum Manuscript containing 173 articles was written on 11 February 1814 (line 669, page 166 recto). the place of where it was written was also stated, but unfortunately, it cannot be read because it was blocked by a red lacquer seal.

The manuscript is fortunately still in a good condition. The whole text is still readable, especially with the help of the zooming tool. In the top right-hand corner of the recto page of 155, there is a written text "Honble Lieut. Governor", which is the short abbreviation for "Honorable Lieutenant Governor". In addition, in the bottom left-hand corner, the Arabic number "155" is written using a pencil. It was presumably added by the collection officer of the British Library. Similar writings 
are found in all recto pages. There are also catchwords in some verso pages, which are 156, 158, 160,162, and 164.

At the bottom left-hand corner of recto page 158, there is also a vertical-oriented scratch that is similar to kanji letters. Unfortunately, we do not have the ability to read and interpret the meaning of scratch. At the bottom of the recto page 166, as we have stated previously, there is Raffles' signature and a red rounded-seal. The seal actually contains image and letters which, unfortunately, can not be identified even through the zooming technique. Meanwhile, page 166 verso is blank. However, there are two lines of writing which are: "Malay Translation of the Police \& Judicial Regulations".

The Kitab Hukum Manuscript, by referring to a sentence in Article 173 (page 166 recto, line 665 to 666), is not a single copy. The text in the Kitab Hukum Manuscript is the translation of the "original text" written in Roman script and English language. We found the "original text" in the Substance of a Minute Recorded by The Honorable Thomas Stamford Raffles, Lientenant-Governor of Java and its Dependencies, on the 11th February 1814; on the Introduction of an Improved System of Internal Management and the Establishment of a Land Rental on the Island of Java. It was oringinally printed in London by Black, Parry, and Co, but it was unpublished. Raffles also attached the regulation in his monumental work, the History of Java. According to Article 173, the "original version" of which was also translated in the Javanese language by using Javanese script. Unfortunately, so far, we have not found the manuscript yet.

In general, there are two matters that were governed by the Kitab Hukum; they are as follows: 1) the structure of the judiciary; and 2) the duties and functions of the judicial institutions (and their officials). Nevertheless, the regulation did not divide the duties between the executive and the judicial power holders like what exist in recent Indonesia. A resident, for example, in addition to performing executive duties (governmental), also carried out judicial duties as a judge (head of court). This regulation and roles were also applied to officials below him, namely the regents and the heads of division.

Actually, the Kitab Hukum manuscript does not directly address the judicial system as well as the main duties and functions of the judicial institution. The first six articles in the manuscript describe the "general provisions" related to the distribution of power in stages, from the resident, the bupati (head of district), the kepala babagian kecil (head of 
division), to the kepala kampung (head of the village). It is also explained that every residency shall be divided into a number of districts that will be adjusted to the size of territory, population, or former customs. Furthermore, every district shall be divided into a number of divisions ${ }^{4}$. It is clearly stated in the manuscript that the area of each division should not be less than 10 paal but no more than 20 paal. ${ }^{5}$ It is also stated that the boundaries of each division are the outermost villages, and is not always based on the size of the territory "...so that the inhabitants of a village are not governed by two powers" (recto 155, Article 5, line 23).

The Kitab Hukum Manuscript then explains the main tasks and functions of the regional officials in stages, starting from the head of the village (with various titles of it, such as petinggi, bekel, lurah, kunn and mandor). There are 18 articles (Article 7 until 24) governing the tasks for maintaining security and public order. The task was attached to the heads of the village and the police officers. The heads of the village should receive and carry into execution all orders from the Government-which are lowered in stages from the governor to the residents, bupatis, and heads of divisions - and disseminate them to the public. Furthermore, they should be responsible for security and regional peace. The heads of the village were also directed to keep a register of all individuals under their authority, describing the name, age, country, occupation, size, and appearance of each individual, with any other remarks that may be deemed necessary; and these will be drawn up every six months. Moreover, they-along with the police officers - are authorized to apprehend any individuals that have done criminality (accompanied by evidence or complaints). Finally, the heads of the village have the right to receive rewards of a certain portion of land and guaranteed protection from the government.

Next, there are 33 articles covering the main duties and functions of the heads of division (Article 25 until 57). In addition to being responsible for administrative and police affairs, every head of division

\footnotetext{
${ }^{4}$ Equal to the kecamatan. De Klein (1931) preferred to use the term "cutak" for this region.

5 In Malay version of the manuscript; In the English version, the width of each division was expressed in square miles. Paal is a long measure, while square miles is a large measure. Paal conversion is different. In Java, 1 paal is equal to 1,507 meters, while in Sumatra 1,852 meters (Sastrodinomo, 2009). The online version of Kamus Besar Bahasa Indonesia contains a 'pal' entry which means 'a milestone as a mark of distance, between one milestone and another 1,5 km'.
} 
also has judiciary power. Article 47, for example, states that the head of divisions - with mantri and other helpers - must be at the paseban (open space) at the police station, at least once a week, to examine and resolve cases occurring in their respective territory. However, their authority is limited to small cases, such as trespassing, nuisance, solving the unfair distribution of water, and other such minor grievances of usual occurrence in the village. They are entitled to conduct a hearing on cases as well as making decisions on civil cases that may be referred to them, provided that the amount of the fine at issue does not exceed 20 rupiahs. In addition, they are also authorized to sanction a fine with limitation that it does not exceed 10 rupiahs) but not to catch or imprison people.

Furthermore, the Kitab Hukum Manuscript also govern and regulate the main duties and functions of bupati (the heads of the district) arranged into 26 articles (article 58 to 83). At the district level, the government had established a regular court headed by the bupati (regent) ${ }^{6}$. Nevertheless, the district courts were only authorized to handle civil cases with no less than 20 rupiahs and no more than 50 rupiahs. Meanwhile, the handling of all other criminal cases, except for a small portion submitted to the head of the division, was the authority of the Resident Court.

For the next level, there are 67 articles (Article 84 to 150) governing about the main duties and functions of the residents. In trial practices, the resident acted as a single judge ${ }^{7}$. The bupatis (or patibs) must attend the court sessions in the Resident Court to expound their opinions and/or information as required. The head jaksa and the penghulu were also obliged to attend and were in charge of explaining the applicable laws, customs, and taking testimony from the witnesses. Meanwhile, jaksa of the district, acted as public prosecutors. In addition, the trial was also attended by a number of other officials in accordance with the customs in that area.

The Resident Court authorized to handle civil and criminal cases, both original and appeal cases from the previous court. But, for civil cases, the value should not be less than 50 rupiahs. As for criminal cases, the Resident Court can only handle criminal cases that do not cause a death penalty. Any criminal acts that caused a death penalty

\footnotetext{
${ }^{6}$ If he was unable to do so, he might hand over the duty to the patih.

${ }^{7}$ He was also permitted to submit duties to the assistant-resident if he absents.
} 
should be handled by the Court of Circuit (Raad Sambung/Raad Keliling). The resident only had the right to charge the suspect of imprisonment. The rules in the Kitab Hukum also require the resident to be responsible for the management of the prison. At least once in every two weeks, the residents must visit it to monitor directly (and also to receive reports) on the healthcare services for prison inmates and the warder's behaviors. As regards to health care, the resident must bring in a doctor to check the prisoners at least once a day. The doctor must submit a monthly report to the resident.

Lastly, the Kitab Hukum Manuscript governs the basic tasks and functions of the Court of Circuit and explain them in 21 articles (Article 151 to 171). The Court of Circuit was not a regular court; it was only held at least four times a year. The court leader is a member of Raad van Justitie (Court of Justice) in Batavia, Semarang, or Surabaya. One of them is assigned to make a circuit through the districts that are under the Raad van Justitie. Trials are then held at the place that is usually used by the residents. Therefore, the residents must find other places to hold their Residential Court during the Raad Sambung court sessions.

One thing that distinguishes Raad Sambung with other courts is the presence of another "party" called the jury. The manuscript mentioned that the jury shall consist of five people. The individuals composing this jury ought to be as near on an equality, as to rank in life, with the prisoner as possible. Nonethelless, no one under the rank of a head of a village can be considered as competent to act as a juryman due to a rule that individuals below that office are not supposed to posses independence or knowledge that is sufficient to qualify them to justly execute the duties of the situation. The jury panel with the highest rank will be automatically picked as the coordinator. It is also stated that both the prosecutor and the prisoner have the right to accept or reject a jury member like the mechanism within the English court. In trial practices, Raffles-as Lieutenant-Governor Jawa and Its Dependencies-became the final decision maker, especially for two matters. First, whenever the opinions of the Pengbulu and the Jaksa shall be in opposition to that of the head of court; or, second, in which the punishment of the crime shall amount to imprisonment or transportation for life. These are stated in Article 106 of the Kitab Hukum manuscript. 
The following is the judicial institution structure as had regulated in the manuscript:

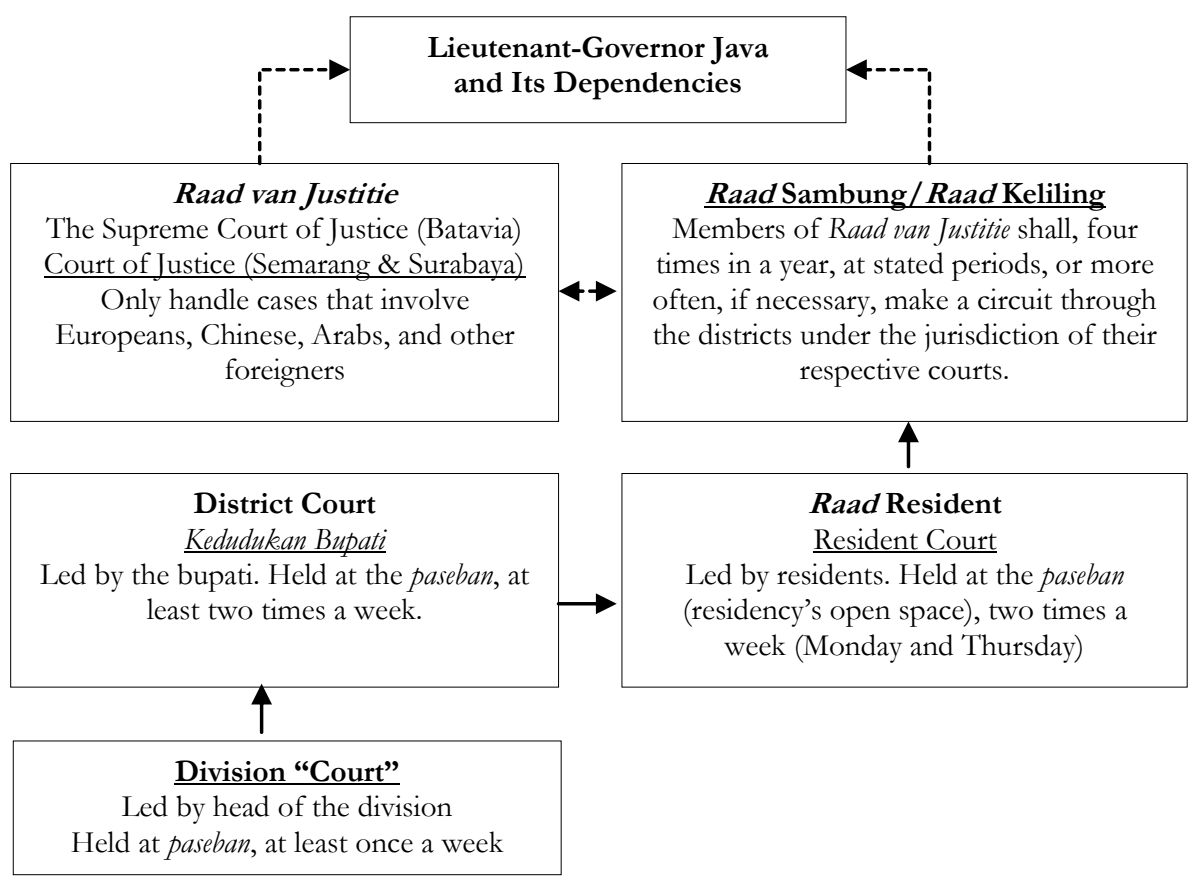

There are 10 articles in the Kitab Hukum manuscript that had governed the function and position of penghulu; they are Article 65, 65, 66, 77, 88, 90, 105, 106, 107, 125 and Article 165. As mentioned before, we just know that Article 65, 66 and 77 are in the domain of the District Courts while Article 88, 90, 105, 106, 107 and Article 125 are in the domain of the Resident Courts and, lastly, the Article 165 is in the domain of the Court of Circuit.

At the District Court, the penghulu—along with the jaksa-has the authority to accept and then review an inquest report that had conducted by the head of division (Article 65). The penghulu-along with the jaksa and other law officers-also assisted the bupati or patih to hold the court (Article 66). The penghulu—along with the jaksa-will be summoned by the bupati throughout the trial to expound the law where it is unclear. If his opinions concur with that of the head of the court, the case can be decided immediately. But if the penghulu 
opinions are at variance, the bupati shall refer the case, with the several reasons detailed which have influenced each opinion, to the resident. The resident then discusses with the jaksa and the panghulu before return his orders on the case (Article 77).

At the Resident Court, the penghulu—and the jaksa-must take an oath which basically consist of two points. Firstly, they will answer all of the questions, both verbally and in writing, submitted by the judge or the head of the court. Secondly, the penghulu—and the jaksa-will give a statement freely, without fear or partiality, about the written acknowledged law or the local long-established usage. They also will not declare all matters that are not warranted by the law or custom (Article 88). The penghulu - and the jaksa-if necessary, will expound the law and the local usage, and take down notes of the evidence (Article 90). If their opinions are in accordance with the resident, and in which the punishment is not too heavy (such as imprisonment or transportation for life), the sentence must immediately be decided (Article 105). If there is a diversity of opinions or in which the punishment is too heavy, the resident must transmit the case to the government. The decision must be delayed until he receives the orders from the Lieutenant-Governor (Article 106). The penghulu -and the jaksa-- are ordered to take notes of the evidence, and to state their respective opinions on the case, in the vernacular language (Article 107). The opinions of the penghulu-and the jaksa-must be considered, both in civil cases and in criminal cases. If their opinions shall be in opposition with the resident, the case must be transmitted to the Lieutenant-Governor. The resident shall pronounce the sentence in accordance with the order of the Lieutenant-Governor (Article 125).

Meanwhile, in the Court of Circuit, there is a provision that the judge must ignore all indigenous legal rules as may be expounded by the penghulu and jaksa. He must only consider the colonial law, as to be applied in Java, for his decision so that the law could fulfill the acknowledged principles of substantial justice.

\section{The History of Penghulu, from Raden Patah to Daendels}

The institution of penghulu was established during the reign of Raden Patah, the first sultan of Demak (enthroned in 1475 AD). At a certain level, the definition of the "penghulu" refers to the qädi function in a number of Islamic countries. In addition, the penghulu in the 
Javanese culture context was an executive of one of the three responsibilities of the sultan, namely as Sayidin Panatagama Kalipatullah. Therefore, he had a full responsibility for implementation of various tasks related to religious obedience, such as religious rituals, family law, wali hakim, religious education, and sermons. Meanwhile, one of his prominent duties is, as previously mentioned, being the head of the court. Later on, this court, in Yogyakarta and Surakarta, was called the Surambi Court while in Cirebon it was called as the Penghulu Court.

The jurisdiction of the penghulu was not only limited within the internal circle of the keraton (palace) but also exceeds the external of it. Therefore, the institution was established in stages, range from the level of keraton, kawedanan jero (the regency-level areas that are inside of the keraton-circle), kawedanan jaba (the regency-level areas that are outside of the keraton-circle), kapanewon (the district-level areas) and kampung (village). The pengbulu official in the keraton level was called pangulu ageng; it was the highest position of the structure. He also served as the head of the religious department in the keraton. Hence, he was called as wedana kaum or the chief of abdi dalem pamethakan. For the implementation of various tasks related to the religious obedience, the penghulu was helped by a number of officers, such as ketib (from the Arabic word "khattib", 'the sermoner'), mudin (from the Arabic word "mu ażin"), ngulama (from the word "ulamä", 'the scholar') and merbot. Meanwhile, the pengbulu official in the level of kawedanan jero was called pangulu ketib; in the level of kawedanan jaba was called pangulu lurah naib; in the level of kapanewon was called naib; in the level of kampung was called kaum. ${ }^{8}$

The pengbulu, as a head of court, should base his decision on a number of Arabic books of figh written in the span of the twelfth to the sixteenth centuries. Among them is the Moharrar, Mahalli, Tuhpah, Patakulmungin and Patakulwahab ${ }^{9}$. The Moharrar refers to the book of alMuharrar fì Fiqh al-Imàm al-Shäfi'i, a work of Imam al- Rafi'i (555-624 $\mathrm{AH} / 1160-1227 \mathrm{AD})$, one of the books of fiqh that became the main reference in School of Shafi'i. The Mahalli refers to the author's name,

\footnotetext{
8 Muhamad Hisyam, Caught Between Three Fires: the Javanese Pangulu under the Dutch Colonial Administration (1882-1942) (Jakarta: Indonesian-Netherlands Cooperation in Islamic Studies (INIS), 2001), pp. 24, 26.

${ }_{9}^{9}$ Endah Susilantini, Dwi Ratna Nurhajarini, and Suyami, Serat Angger Pradata Awal \& Pradata Akbir di Kraton Yogyakarta: Kajian Filologis Historis (Yogyakarta: Balai Pelestarian Nilai Budaya Yogyakarta, 2014), pp. 23-25.
} 
namely Imam Jalāl al-Dīn al-Mahalli (791-864 AH/1389-1459 AD). Meanwhile, the book that was intended as guidelines for decisionmaking in the Surambi Court is Kanz al-Räghibin, annotations (sharb) on the book of Minhäj al-Tälibin by Imam Nawawi (631-676 AH/12331277 AD). The Tubpah refers to the Tubfah al-Mubtaj by Ibn Hajar alHaytamī (909-973 AH/1503-1566 AD). It is in harmony with the information which was contained in the summary (pépètikan) book of Tuhfah in Javanese ${ }^{10}$. The Patakulmungin refers to the Fath al-Mu' in by Zayn al-Dīn al-Malibari (938-987 AH/1532-1579 AD), an 'ulama's' who was a disciple of Ibn Hajar al-Haytamī. The Patakulwahab refers to the Fath al-Wahhāb by Imam Zakariyya al-Anșāri (824-926 AH/1421-1520 $\mathrm{AD})$, the annotation of the Manhaj al-Tulläb of his own work. While the Manhaj al-Tulläb is a summary (mukbtasar) of the Minhäj al-Tälibin by Imam Nawawi.

Interestingly, since the beginning, it seems that the Demak Sultanate did not want to implement the Islamic law totally to the people of Java. Almost all written rules in the island, indeed, sourced from al-Qur'an with some adaptations to the customs of the local community. At the certain level, as stated by Raffles, the rules based on Islamic teachings were applied, but it was unable to completely replace the ancient beliefs and local customs that had prevailed for a long time. At the time of the Demak Sultanate, the compilation of laws containing the mixture of Islamic law and the customary law was issued. Later on, the compilation of law was well known as the Surya Alam manuscript, a name which referred to Raden Patah, the first sultan of which sultanate. Raffles praised the manuscript as "..a work of repute, the very essence of the laws and regulations that were touted as the earliest that was incorporated into the Javanese tradition"; and it was used as a way to introduce Islamic law as a whole of the people of Java ${ }^{11}$. The condition had continued in time of the Pajang Sultanate (1550-1586) and the Mataram Sultanate (1586-1755). Under the control of the dynasty of the three sultanates, Java was truly successful in being "Islamized", both politically and culturally. As a matter of fact, the existence of the penghulu as a head of court had been retained until

\footnotetext{
10 Taco Roorda, Kitab Toehpah, een Javaansch Handboek voor het Mobammedaansche Recht (Leiden: E.J. Brill, 1895), p. 2.

${ }^{11}$ Thomas Stamford Raffles, The History of Java. Second Edition. Vol. I (London: John Murray, 1830), p. 309.
} 
the bankruptcy of VOC at the end of the eighteenth century. Neverthelless, the judicial system in Java was modified in such a way that it greatly benefited to the Dutch trading company.

The penghulu, during the Demak Sultanate period, was a figure who truly understood the Islamic laws. He also frequently acted as an advisor for the sultan; not only on religious affairs but also on political affairs. It worth noting that, later on, especially after the Mataram Sultanate area was divided into the Yogyakarta Sultanate and the Surakarta Sunanate, the penghulu was not only an 'ulama' but also a figure who must politically secure the power of sultan. At the time, according to Breman, the penghulu came from the menak class or the high-level nobility as well as the sultan, patih, adipati, bupati, the head of jaksa and the heads of the district. Another important fact is that they all have family relationships. They shared a number of key position, including the penghulu, in order to preserve the power ${ }^{12}$. The villagelevel of penghulu who was also called lebe or amil did not only have tasks as a leader of religious activities and the Qur'an teacher for the children, He also helped to collect paddy for zakat. IN this regards, he distribute $1 / 10$ part of paddy harvest for the religious leaders and also — through the district penghulu— to the religious leaders of regency. In addition, the village penghulu—as one of the few people who can read and write-was also assigned to record the births, marriages, and deaths. Later on, he also helped to carry out smallpox immunization for the children, and to collect $1 / 10$ of the produce for the bupati13.

As an appreciation for his efforts, the pangulu ageng was given a salary which was derived from the keraton treasury. Similar to other officers in the keraton circle, he also had a right to manage a plot of land that was commonly called tanah lungguh. At first, the salary for the penghulu was taken from a total 1/10 levy of harvested paddy that was handed over to indigenous rulers. However, in 1809, Daendels increased the levy of paddy to $1 / 5$, of which $1 / 10$ was for the rulers and $1 / 10$ for the religious leaders or the penghulu ${ }^{14}$. At the late of the nineteenth century, the pangulu ageng got a salary of 9 guilders from the court fees that must be paid by the complainant. In addition, he also

\footnotetext{
12 Jan Breman, Keuntungan Kolonial dari Kerja Paksa, Sistem Priangan dari Tanam Paksa Kopi di Jawa, 1720-1870 (Jakarta: Yayasan Pustaka Obor Indonesia, 2014), pp. 42-43.

13 Ibid., p. 44.

${ }^{14}$ Ibid., pp. 106-107.
} 
earned income from pabusur or usur, that was $10 \%$ of the value of inheritance or of gana-gini which was handled by the court ${ }^{15}$.

When the VOC began its trading in Nusantara, that is at the beginning of the seventeenth century, most regions in Java had two types of courts. The first is the court headed by the jaksa that has the authority to deal with criminal cases, such as theft, robbery, and all minor matters. Meanwhile, the rule of law used within the judicial practice was largely influenced by ancient beliefs and local customs. The second is the court that was headed by pengbulu, the supreme leader or the highest authority in religion (Islam) that had the authority to handle divorce, contract, and inheritance cases, and-in some cases - to also take over the jurisdiction of the jaksa court. However, at the time, the VOC only paid attention to the trading affairs. Therefore, it was not a suprise that the first step taken by the Company was focused on the controlling of the sea trade routes in the East Indies, especially in the two strategic straits such as the Malacca Strait and the Sunda Strait. Moreover, it was not easy for VOC to get the trading supremacy because they had to fight with the centers of power in the East Indies and other Western traders, mainly the Portuguese and English. Therefore, all the VOC forces were focused on coastal areas, such as Batavia, Cirebon, and Semarang. Consequently, for quite a long time, the VOC had no idea of the extent and kind of the property of Java that they had occupied since the early seventeenth century. The VOC then entered rural areas in the second half of the seventeenth century. It was also due to the necessity of taking sides in the field of conflict of indigenous political power ${ }^{16}$.

The strategy of the VOC then actually gave a "bonus" to the VOC. Within the next period, the Company was gradually able to control all aspects of the indigenous people's lives, including the field of law where the penghulu played a role in it. By borrowing a term from Hoadley ${ }^{17}$, the VOC carried out a colonialization-shariabization process to present a new face of law in Java. At the level of substantive laws ${ }^{18}$, the Company used as many rules as possible within the Javanese legal

\footnotetext{
${ }^{15}$ Hisyam, Caught between Three Fires, p. 29.

${ }^{16}$ Breman, Keuntungan Kolonial, p. 14.

17 Mason C. Hoadle, Islam Dalam Tradisi Hukum Jawa \& Hukum Kolonial (Yogyakarta: Graha Ilmu, 2009).

18 Relates to the material law, which is legislation or written law that regulates the rights and obligations of all parties within the jurisdiction of the law.
} 
treasury by the maximum involvement of local legal instruments, including the pengbulu. However, the VOC gave a note that 'all must still be tolerated'. Meanwhile, at the level of procedural ${ }^{19}$, the implementation of laws must be confirmed with the methods which are set by the Company. It was not surprising then that the final verdict in court proceedings, for the certain criteria of cases, will remain in the hands of the Company's officials. One oxample of this is the trial process in Cirebon. It was stated that if the jaksa (head of the Karta Court or head of the Jaksa Pepitu Court) or the penghulu (head of the Penghulu Court) did not find an agreement, they must submit the case to the sultan. Then, the Sultan will take the final decision, but he must avoid cruel punishments, and even cause disability. In addition, the sultan was also permitted to impose the death penalty, but he had to be approved by the Company's officials in Batavia. ${ }^{20}$ The rules are written on the Pepakem, the compilation book of the law which was issued in $1768 \mathrm{AD}$ and was initiated by the VOC. Since then, the Pepakem had become a reference book for the judges, both in the Karta Court and the Pengbulu Court, in making decisions.

The similar conditions occurred in the "Central Java". In 1754 AD, Governor-General Jacob Mossel, serving at period 1750-1761, ordered the official of Dutch administration to compile the civil rules and customs that had scattered across the country. This act surely was conducted with the help of ulama and the heads of the village. Jacob mossel intended to make a summary book (compendium) of law which can later be used by local judges to take decisions on cases that were filed by indigenous people. After consulting with the penghulu, ulama and the indigenous rulers, Freijer-a person who was appointed to prepare the book-issued the Compendium der voornaamste Mahomedansche wetten en gewoonten nopens erfenissen, buwvelijken en echtscheidingen (The Summary of the Principal Law of Islam and Customs on Inheritance, Marriage, and Divorce). Later on, through the resolutie which was issued on 27 November 1804, the book that was known as Compendium Freijer was revoked because it was considered 'not grounded'. Consequently, it did not function effectively within the law enforcement. Meanwhile, in Semarang, the area which just had been

\footnotetext{
19 Relates to the formal law or the procedural law, which is on how to enforce or execute the material law.

${ }^{20}$ Ibi Satibi, "Produk Pemikiran Hukum Islam di Kerajaan Islam Cirebon Abad Ke-18 M (Studi Atas Kitab Hukum Adat Pepakem)," Saintifika Islamica, 1 (2014), p. 127.
} 
handed over by the Mataram Sultanate to the VOC in 1750, a compendium was also compiled. The compendium is named the Mogharraer and it was intended as a reference book for landraad, a court body headed by the governor and seven regents as the members ${ }^{21}$.

As mentioned previously, at the certain level, rules which were based on the Islamic religion were applied in Java. Yet, it was unable to completely replace the ancient beliefs and local customs that had prevailed for a long time. This is due to the fact that the inhabitants of Java tended to maintain tata tentrem (social harmony) so that they can avoid conflict. Unsurprisingly, the original law applied to the Javanese community that was more normative, carried out flexible. The verdict then was handed over completely to the ruler. Javanese legal texts always provide various categories of problem-solving that can be applied to certain cases. Every time when a case arises to decide a court verdict, the implementing authority must choose a suitable category to be applied so that social harmony (tata tentrem) is recreated. ${ }^{22}$ One example of which was the case of the Bupati of Parakanmuncang in 1717. He accused of involvement in the death of the Dutch Company official who was traveling in the region. The bupati was supposedly punished in accordance with the Islamic law which had contained in the al-Muharrar. However, in fact, he was sentenced by the customary law, named aksara geni, in the form of dismissal from office and status, of property confiscation and of expulsion from the area along with his wife and children. ${ }^{23}$

This information is in line with Raffles statement. ${ }^{24}$ The kings (or sultans) and other court apparatus in Java had the discretionary powers to adapt Islamic laws in accordance with the conditions of the local community. The power was prerogative that can be taken freely. In fact, there are times when sanctions were taken precisely deviating from the provisions of Islamic law and it was incorporated into the customary law (yudha nagara). Raffles exemplified some of the sanctions that had considered to deviate from the provisions of Islamic law. First, by punishing criminals with a dagger, but not by the beheading law. Second, contesting criminals with tigers. Third, imposing severe

\footnotetext{
${ }^{21}$ Hisyam, Caught between Three Fires, p. 50.

22 Hoadley, Islam Dalam Tradisi, p. 14.

23 Ibid., p. 399.

${ }^{24}$ Raffles, The History of Java, p. 313.
} 
punishment for violations of the Javanese revered laws. Fourth, permanently replacing any kind of corporeal punishment with a fine of money. Fifth, when the people of the upper classes was found guilty in a murder case, harsh punishment in the form of qișas (retaliation) was replaced by a fine, regardless of the wishes of the family of the victim. The composition of the court in Java, including the law books that were in effect, had not changed since the days of the VOC to the British interregnum period.

Herman Willem Daendels, shortly after he became a governorgeneral in 1808, decided to directly intervene in law enforcement; whereas he had never once set foot in the land of Java. He also gained knowledge of the island through the official government reports. Perhaps because of having a legal education background even to the doctoral level, Daendels could immediately be seen that the law enforcement in Java did not go well. Even so, he brought the old assumption that the law that running of the Javanese people was the Islamic law. No wonder then he involved penghulu in all types of court for the indigenous people, such as Ambulant Landgerecht voor de Jaccatrasche en Preangerbovenlanden and V redegericht. At the types of court, the penghulu was become as the member of judges, together with prefect, bupati and overseer. Daendels also involved the penghulu for the court that had organized by colonial officers, but only being an advisor. It was because pengbulu was an expert on Islamic law so he had to be presented to the court then he expounds his opinions about the case being handled. Daendels, as stated by Hisyam, was the first governor-general who encouraged the pengbulu in his capacity as a "high priest" to take part in running the colonial administration. ${ }^{25}$

\section{The Reason of Issuing the Kitab Hukum}

Raffles, on third years of his serving as Lieutenant-Governor of Java and Its Dependencies, issued the Kitab Hukum Manuscript. Based on that regulation, as we previously mentioned, the penghulu no longer had the authority to handle and decide cases which had brought to the court. He only authorized to answer various questions submitted by the head of the court, both in regarding Islamic law and customary law, related to the cases which were being handled. Even, in the Court of Circuit, the opinions that may be expounded by penghulu were ignored.

${ }^{25}$ Hisyam, Caught between Three Fires, p. 54. 
Raffles ordered the head of court to only considered the provisions of the colonial law in making decisions 'so that the law could fulfil the acknowledged principles of substantial justice'.

Raffles stated in the introduction section of the Kitab Hukum manuscript that the implementation of the law in Java was to be maximally protected. Therefore, he issued regulation deriving from the custom and usage of the Javanese inhabitants because it was considered more feasible to implement than the new regulations set by the European. However, in a report to Lord Minto, who was serving as Governer-General of the East India Company, Raffles acknowledges that he issued the regulation in order to improve the British revenue management from Java. ${ }^{26}$ In this context, economic motives were very prominent, just as the VOC had done.

Before issuing the new regulations, he collected a considerable amount of information, both from colonial officials and native authorities, then consult it.

"In the course of my several journies through the Island, I was enabled to collect very considerable information; and the replies to my letters from the different Residents, put me in possession of materials, quite sufficient to form the groundwork of a general Regulation on the subject". ${ }^{27}$

Since taking the post as the lieutenant-governor, Raffles made regular visits to the area. In December 1811, he visited the Yogyakarta Sultanate "in order to establish relations between the two governments in an agreement..." In May 1812, he was in Cirebon. ${ }^{28}$ Four months later, Raffles visited the eastern tip of Java. ${ }^{29}$ In addition, he had also received reports from David Hopkins and John Crawfurd. At the time, Hopkins held the position of Commissioner for Settling District Revenues, while Crawfurd held the Resident in Yogyakarta. However, in the report for Lord Minto, Raffles only referred the report by

26 Thomas Stamford Raffles, Substance of a Minute Recorded by The Honourable Thomas Stamford Raffles, Lieutenant-Governor of Java and its Dependencies, on the 11th February 1814; on the Introduction of an Improved System of Internal Management and the Establishment of a Land Rental on the Island of Java (London: Black, Parry, and Co (Printed but not published), 1814), p. 155.

${ }^{27}$ Ibid., p. 162.

${ }^{28}$ Major William Thorn, Memoir of The Conquest of Java (Singapura: Periplus, 2004), pp. 122, 165.

${ }^{29}$ Raffles, Substance of a Minute Recorded, p. 28. 
Hopkins. It was stated that the Java inhabitants already had rules of law which had considered very good. They had already integrated customary laws that were inherited by the ancestors with the Islamic values, the religion that presented later. However, none of which was applied 'nationally'.

That condition made Raffles felt the need to issue a regulation for all inhabitants of Java that became the perfection of the original indigenous law. He reasoned that all the changes in consideration to support the industry and eliminate oppression and political oppression will be useless if there is no such development in the law on justice and the police, as well as privileges to be granted. ${ }^{30}$ Raffles, as stated by Day. ${ }^{31}$ succeeded in implementing a more efficient judicial system on Java and in establishing principles so as to establish a judicial relationship with the indigenous people. It was the fruit of Raffles' hard work in gathering information about the original customs, especially with regard to the judicial system. He also succeeded in inducing the indigenous people to hand all cases to the courts under European influence. However, in reality, the implementation of a European-style court was opposed by many indigenous figures; and it actually happened at least since the end of the seventeenth century until the end of the Java War in 1830. It was mainly about the provision that all cases involving the indigenous people in keraton (Yogyakarta and Surakarta) with foreigners, ${ }^{32}$ especially Chinese, were tried under the colonial laws, not the Islamic-Javanese law anymore. The indigenous people had been forced to settle cases under legal norms which they did not understand.

During British rule, there were many cases involving the indigenous people and the Chinese people, especially regarding the imposition of corrupt and oppressive taxes. According to Carey, ${ }^{33}$ Raffles did not issue the rules which were completely new, but he cited the contents of the Mataram Sultanate agreement with the VOC in

\footnotetext{
${ }^{30}$ Raffles, The History of Java, pp. 320-321.

31 Clive Day, The Policy and Administration of the Dutch in Java (New York/London: The Macmillan Company, 1904), p. 195.

32 The foreign category also includes Javanese and Muslims, but they were not born in the Yogyakarta Sultanate and the Surakarta Sunanate.

33 Peter Carey, Kuasa Ramalan: Pangeran Diponegoro dan Akbir Tatanan Lama di Jawa, 1785-1855, Three volumes (Jakarta: Kepustakaan Populer Gramedia dan Koninklijk Instituut voor Taal-, Land- en Volkenkunde, 2012), pp. 450-451.
} 
1677. The agreement had been signed by the second Susuhunan Amangkurat (served in period 1677-1703). The rules were strengthened through the 'coronation' agreement of the second Sultan Hamengkubuwana of Yogyakarta with the VOC on 2 April 1792. Before 1812, however, the sultans in Java ignored the rules. The second Sultan Hamengkubuwana, for example, did not allow his people to go to Semarang to attend a trial in Raad van Justitie. The fourth Pakubuwana of Surakarta who served in period 1788-1820 even continued to urge that the matters involving the Chinese people be returned under his rule of law. He reasoned that the people of Surakarta had felt the suffering, both in time and cost, for undergoing legal proceedings with an increasingly alien system. The religious groups in that area were also furious with the fact that the Surambi Court no longer had full authority to handle criminal cases. One of the figures who strongly opposed was Pangeran Diponegoro (1785-1855). He stated that the European government on Java had created enormous misfortune because it alienated Javanese people from the divine law brought by the Prophet Muhammad.

So, it is quite clear that the measures of which Raffles took did not solve all problem. Rather, he, even had made a serious blunder by introducing the British jury system to the inhabitants of Java. The Raffles' regulation, as judged by $\mathrm{Veth}^{34}$, have at least four weaknesses. First, the mixing of power. This is in line with the involvement of the 'High Government' (de Hooge Regeering; the Supreme Government) in routine legal administration activities. Secondly, the 'awkwardness' of the High Court's position (Raad van Justitie; the Court of Justice) serves as an appeals court. The decision, however, depends on the courts in Batavia (the Supreme Court of Justice). Third, the presence of the jury institution, whereas the number of European citizens in three major cities (Batavia, Semarang, and Surabaya) was very small. Fourth, the indigenous people's ignorance of efforts to echo high-level development and their indifference to a sense of justice and morality. De Klein admitted that, conceptually, Raffles did bring big changes in the judicial system in Java. However, he doubted that the published

34 P.J. Veth, Java: Geographisch, Ethnologisch. Historisch. Tweede Druk. Tweede Deel: Nieuwe Geschiedenis (Haarlem: De Erven F. Bohn, 1898), p. 321. 
regulations were effectively implemented. Moreover, not all officials are loyal to him. ${ }^{35}$

\section{Conclusion}

The penghulu institution had been established in the early days of the Demak Sultanate. He was a high-level of sultanate official who had responsibility for implementation of the Islamic rules in the whole country, both inside and outside the circle of keraton. Therefore, the penghulu must be a person who had understood very well about Islamic law (fiqh), both theoretically and practically. Moreover, one of his most prominent tasks was to lead the court.

In the following period, especially after the area of Mataram Sultanate was divided into the Yogyakarta Sultanate and the Surakarta Sunanate, the penghulu was no longer an 'ulamä', but also a politician. It was because the penghulu was one of the key positions that had become a supporter of power eternity. On the other hand, the penghulu was still leading the court, but he can no longer be independent in issuing decisions. At the certain cases, he must consult even received orders from the sultan or the VOC official before he pronounced the sentence. That condition lasted until the end of the eighteenth century along with the bankruptcy of the Dutch trading company.

Herman Willem Daendels, who served as governor-general in period 1808-1811, began to involve the penghulu again as a member of the council in all types of courts for the indigenous people, such as the Ambulant Landgerecht voor de Jaccatrasche en Preangerbovenlanden and $\checkmark$ redegericht. The penghulu was also involved in courts which were held by colonial officials, but he limited to being advisors. At the British interregnum period, however, the pengbulu only functioned as an expert who had presented to the court. He must expound about Islamic law or customary law which were related to cases that were being handled by the court. []

35 Jacob Wouter de Klein, Het Preangerstelsel (1677-1871) en Zijn Nawerking (Delft: N.V. Technische Boekhandel \& J. Waltman Jr, 1931), p. 70. 


\section{References}

\section{Books and Articles}

Bastin, John. "Foreword Provenance of the Raffles Malay Letters". Ahmat Adam. Letters of Sincerity: The Raffles Collection of Malay Letters (1780-1824, A Descriptive Account with Notes and Translation. Kuala Lumpur: The Malaysian Branch of the Royal Asiatic Society, 2009.

Breman, Jan. Keuntungan Kolonial dari Kerja Paksa, Sistem Priangan dari Tanam Paksa Kopi di Jawa, 1720-1870. Jakarta: Yayasan Pustaka Obor Indonesia, 2014.

Carey, Peter. Kuasa Ramalan: Pangeran Diponegoro dan Akbir Tatanan Lama di Jawa, 1785-1855. Three Volumes. Jakarta: Kepustakaan Populer Gramedia dan Koninklijk Instituut voor Taal-, Land- en Volkenkunde, 2012.

Clive Day. The Policy and Administration of the Dutch in Java. New York/London: The Macmillan Company, 1904.

De Klein, Jacob Wouter. Het Preangerstelsel (1677-1871) en Zijn Nawerking. Delft: N.V. Technische Boekhandel \& J. Waltman Jr, 1931.

Hisyam, Muhammad. Caught between Three Fires: the Javanese Pangulu under the Dutch Colonial Administration (1882-1942). Jakarta: IndonesianNetherlands Cooperation in Islamic Studies (INIS), 2001.

Hoadley, Mason C. Islam Dalam Tradisi Hukum Jawa \& Hukum Kolonial. Yogyakarta: Graha Ilmu, 2009.

Mss Eur. D.742/1, ff. 155-166. "Malay Translation of the Police \& Judicial Regulations". 1814.

Raffles, Thomas Stamford. The substance of a Minute Recorded by The Honourable Thomas Stamford Raffles, Lieutenant-Governor of Java and its Dependencies, on the 11th February 1814; on the Introduction of an Improved System of Internal Management and the Establishment of a Land Rental on the Island of Java. London: Black, Parry, and Co (Printed but not published), 1814.

- The History of Java. Second Edition. Vol I. London: John Murray, 1830. 
Roorda, Taco. Kitab Toehpah, een Javaansch Handboek voor het Mohammedaansche Recht. Leiden: E.J. Brill, 1895.

Sastrodinomo, Kasijanto. "Mil, Kilometer, dan Pal". <http://cetak.kompas.com/read/xml/2009/07/31/03141170/ mil.kilometer.dan.pal> accessed on 30 July 2017.

Satibi, Ibi. "Produk Pemikiran Hukum Islam di Kerajaan Islam Cirebon Abad Ke-18 M (Studi Atas Kitab Hukum Adat Pepakem)". Saintifika Islamica, 1 (2014).

Susilantini, Endah, Dwi Ratna Nurhajarini, and Suyami. Serat Angger Pradata Awal \& Pradata Akbir di Kraton Yogyakarta: Kajian Filologis Historis. Yogyakarta: Balai Pelestarian Nilai Budaya Yogyakarta, 2014.

Thorn, Major William. Memoir of The Conquest of Java. Singapore: Periplus, 2004.

Veth, P.J. Java: Geographisch, Ethnologisch. Historisch. Tweede Druk. Tweede Deel: Nieuwe Geschiedenis. Haarlem: De Erven F. Bohn, 1898. 